\title{
The implication of mass elevation effect of the Tibetan Plateau for altitudinal belts
}

\author{
YAO Yonghui ${ }^{1}$, XU Mei2, 'ZHANG Baiping1,3
}

1. State Key Laboratory of Resource and Environmental Information System, Institute of Geographic Sciences and Natural Resources Research, CAS, Beijing 100101, China; 2. China Institute of Water Resources and Hydropower Research, Beijing 100044, China; 3. Jiangsu Center for Collaborative Innovation in Geographical Information Resource Development and Application, Nanjing 210023, China

Abstract: The heating effect (or mass elevation effect, MEE) of the Tibetan Plateau (TP) is intense due to its massive body. Some studies have been undertaken on its role as the heat source in summer and its implications for Asian climate, but little has been known of the implications of its MEE for the distribution of mountain altitudinal belts (MABs). Using air temperature data observed and remotely sensed data, MAB/treeline data, and ASTER GDEM data, this paper compares the height of MABs and alpine treelines in the main TP and the surrounding mountains/lowland and explains the difference from the point of view of MEE. The results demonstrate: 1) at same elevation, air temperature and the length of growing season gradually increase from the eastern edge to the interior TP, e.g., at $4500 \mathrm{~m}$ (corresponding to the mean altitude of the TP), the monthly mean temperature is $3.58^{\circ} \mathrm{C}$ higher (April) to $6.63^{\circ} \mathrm{C}$ higher (June) in the interior plateau than in the Sichuan Basin; the $10^{\circ} \mathrm{C}$ isotherm for the warmest month goes upward from the edge to the interior of the plateau, at $4000 \mathrm{~m}$ in the Qilian Mts. and the eastern edges of the plateau, and up to $4600-5000 \mathrm{~m}$ in Lhasa and Zuogong; the warmth index at an altitude of $4500 \mathrm{~m}$ can be up to $15^{\circ} \mathrm{C} \cdot$ month in the interior TP, but much lower at the eastern edges. 2) MABs and treeline follow a similar trend of rising inwards: dark-coniferous forest is 1000-1500 m higher and alpine steppe is about $700-900 \mathrm{~m}$ higher in the interior TP than at the eastern edges.

Keywords: Tibetan Plateau; mass elevation effect; mountain altitudinal belt; treeline; the warmth index; the $10^{\circ} \mathrm{C}$ isotherm in the warmest month

J. Geogr. Sci. 2015, 25(12): 1411-1422

DOI: $10.1007 /$ s $11442-015-1242-3$

\section{Introduction}

More than one hundred years ago, De Quervain (1904) proposed the concept of Massenerhebungseffekt (Mass elevation effect, briefly MEE) to account for the observed tendencies in temperature-related parameters, such as treeline and snowline, to occur at higher elevations in the central Alps compared to their outer regions. This phenomenon has also been discovered and reported in other places around the world (Leuschner, 1996; Holtmeier, 2003; Flenley, 2007; Barry, 2008). Due to MEE, growing season is relatively longer and warmer at any given elevation in the central mountain ranges. These favorable conditions make treeline rise for about $400 \mathrm{~m}$ higher in the central Alps compared to the outer ranges (Holtmeier,

Received: $2015-04-30$ Accepted: $2015-05-27$

Foundation: National Natural Science Foundation of China, No.41571099; No.41001278

Author: Yao Yonghui (1975-), PhD, specialized in GIS/RS application and mountain environment. E-mail: yaoyh@ lreis.ac.cn

"Corresponding author: Zhang Baiping (1963-), Professor, E-mail: zhangbp@1reis.ac.cn 
2003). Grubb (1971) also stated that the upper limit of lowland rain forest is at about 700-900 $\mathrm{m}$ and that of lower montane rain forest at about $1200-1600 \mathrm{~m}$ on small, isolated mountains and outlying ridges of major ranges, whereas approximately $1200-1500 \mathrm{~m}$ and $1800-2300 \mathrm{~m}$, respectively, on the main ridges of major ranges. Similar phenomena were observed on the TP, Andes and other large mountains and plateaus. In the southeastern TP, alpine treelines climb up to approximately 4600-4700 $\mathrm{m}$ (Troll 1973; Zheng and Li, 1990) and even higher (4900 m) on a few sunny slopes (Miehe et al., 2007), which represent the highest treeline in the Northern Hemisphere. The highest snowline in the Northern Hemisphere also distributes on the TP, at about $6000 \mathrm{~m}$, but in the southwestern TP (Shi et al., 1992; Han et al., 2011).

The heating effect of the TP was identified as early as the 1950s. Flohn (1957) and Ye (1957) separately found that the TP was a summertime atmospheric heat source. Since then, it has been related to Eurasian weather and climate and even to the atmospheric general circulation (Ye, 1982; Ye and Wu, 1998; Yanai and Wu, 2006; Ye and Chang, 1974; Chen et al., 1985; Wu et al., 1997; Zhao et al., 2013). Flohn (1953) first proposed that elevated plateau surfaces, such as those of Tibet and the Altiplano in South America, are warmer in summer than the adjacent free air as a result of the altitudinal increase in solar radiation and the substantial longwave radiation at higher elevation. Barry (2008) noted that sensible heat transferred from the surface and the latent heat of condensation due to precipitation from orographically induced cumulus cloud development contributes to the heating effect in the mountain atmosphere. Ye (1982) calculated the sensible heat and the latent heat of the TP. Over the drier western part of the TP, the sensible heat flux is significant and the total daily sensible energy transfer from the plateau surface to the atmosphere reaches $220 \mathrm{Wm}^{-2}$ in June. East of longitude $85^{\circ} \mathrm{E}$, the latent and sensible heat fluxes are nearly identical (90 and 100 $\mathrm{Wm}^{-2}$, respectively). The maximum heating rates in June for the layer between 600 and 150 $\mathrm{mb}$ amount to $+1.8^{\circ} \mathrm{C}$ day $^{-1}$ from sensible heat, $+1.4^{\circ} \mathrm{C}$ day ${ }^{-1}$ from latent heat, and radiative cooling of $-1.5^{\circ} \mathrm{C}_{\text {day }}{ }^{-1}$, giving a net heating of $+1.7^{\circ} \mathrm{C}$ day ${ }^{-1}$. Various estimates suggest that the heating is about $2^{\circ} \mathrm{C}$ day ${ }^{-1}$ over the eastern half of the Plateau (Chen et al., 1985). Moreover, due to the heating effect of the TP, it is an important negative vorticity source of the summer atmospheric movement (Wu et al., 2005).

Such substantial heating must have large effects not only on the climate of the TP but also the ecological patterns of the plateau, especially the spatial pattern of mountain altitude belts (Zheng and Li, 1990; Liu et al., 2003). Yao and Zhang (2013a, 2013b, 2013c, 2014) studied quantitatively the mass elevation effect of the plateau by comparing monthly mean air temperature differences at given elevations of 4000, 4500, 5000, 5500 and $6000 \mathrm{~m}$ between the main plateau, the Qilian Mts. in the northeastern corner of the plateau and the Sichuan Basin to the east of the plateau, and discussed the implications of mass elevation effect for treelines by considering the $10^{\circ} \mathrm{C}$ isotherm for the warmest month and warm index of $15^{\circ} \mathrm{C} \cdot$ months. However, the implication of mass elevation effect for the whole ecological pattern of the plateau has been rarely involved. This paper intends to explore the implication of mass elevation effect for altitudinal belts with observed and estimated air temperature data, DEM and altitudinal belt data.

\section{Study area}


The study area is located between latitudes $25^{\circ}-40^{\circ} \mathrm{N}$ and longitudes $75^{\circ}-105^{\circ} \mathrm{E}$ (Figure 1), including the entire TP and adjacent areas. The plateau covers an area of nearly 2.5 million $\mathrm{km}^{2}$, mostly between 4000 and $6000 \mathrm{~m}$ above sea level (asl). The Himalayan, Hengduan and Kunlun Mountains are situated on the southern, eastern and northern borders of the plateau, respectively. The Gangdisê and Tanggula Mountains lie in the interior TP and divide the main plateau into three parts (i.e. the southern, central and northern main plateau). The Qaidam Basin, located in the northeast of the TP, is approximately only $3000 \mathrm{~m}$ asl and separates the Qilian Mts. from the main plateau.

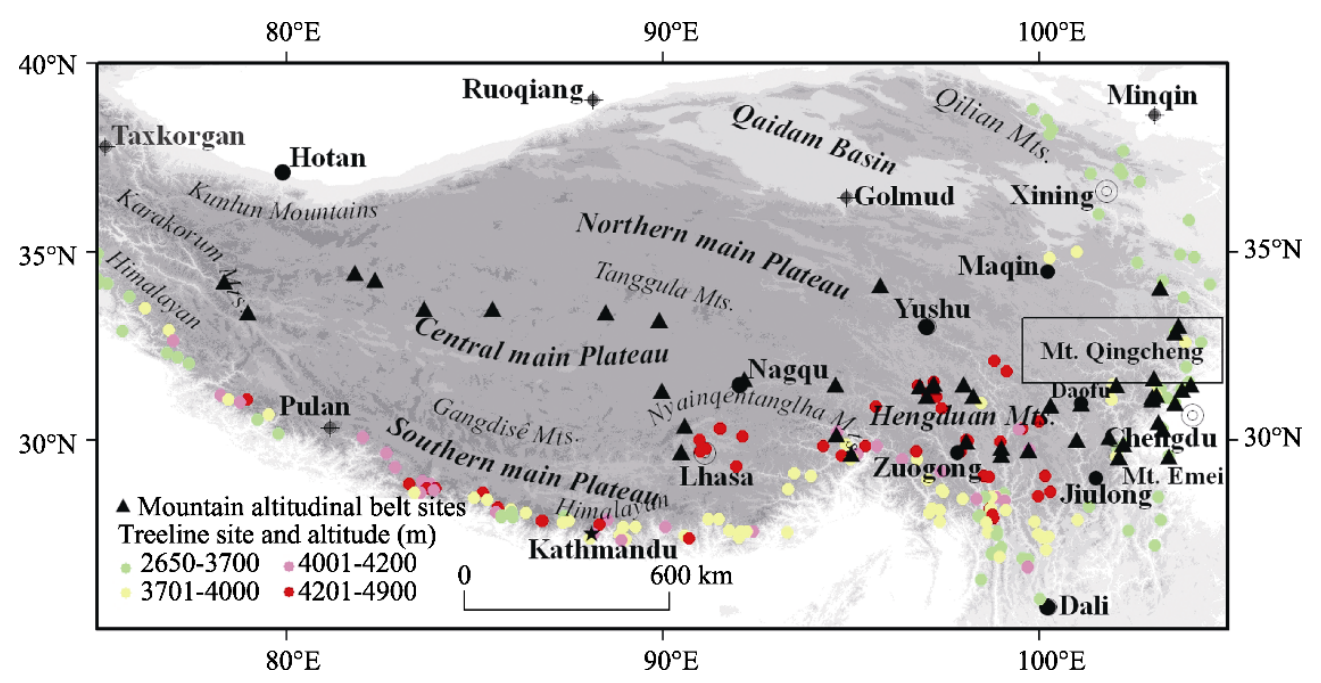

Figure 1 Sketch map of the Tibetan Plateau and treeline and mountain altitudinal belt sites

\section{Data and data sources}

\subsection{Air temperature data}

Two kinds of air temperature data are used in this paper. Observed air temperature data were downloaded from the China Meteorological Information Center (http://cdc.cma.gov.cn/ index.jsp). MODIS land surface temperature (LST) data were processed with meteorological data for 2001-2007 from 137 stations and the ASTER GDEM data (Yao and Zhang, 2013). The MODIS LST data were the Terra Monthly Land Surface Temperature/Emissivity (MOD11C3) product at $0.05^{\circ}$ geographic Climate Modeling Grid (CMG) spatial resolution, downloaded from the Land Processes Distributed Active Archive Center (https://lpdaac. usgs.gov/lpdaac/products/modis_products_table). Geographical weighted regression (GWR) methods were used to estimate air temperature, and the root mean square error (RMSE) for each month ranges from $1.13^{\circ} \mathrm{C}$ for August to $1.53^{\circ} \mathrm{C}$ for March. These data such estimated are spatially continuous and contain more detailed air temperature information than the observed but rather scattered data.

\subsection{Mountain altitudinal belt (MAB) and treeline data}

Zhang et al. (2008, 2009) collected 544 spectra of mountain altitudinal belts, 594 sites for treeline data, and 148 sites for snowline data from the published literature for the global and 
integrated them into a digital mountain altitudinal belt information system. Of them, a total of 267 treeline and 39 MAB data are used in this paper.

\section{Methods}

Montane dark coniferous forest, alpine shrub meadow, alpine meadow, and treelines are taken into account along three profiles (the Mt. Erlang-Nyainqentanglha profile: along Mt. ErlangMt. Gaoshi-Nyainqentanglha Mts.; the Mt. Guangguang-Tuoba Beishan profile: along Mt. Guangguan-Mt. Siguliang-Tuoba Beishan, and the Mt. Wutai-Amugang profile: along Mt. Wutai-Tanggula Mts. -Amugang), to study the distribution principles of the limits of MABs, and to calculate the mass elevation effect as temperature difference at the same elevation between the interior TP and the outer edges. Lastly, the mean temperature and the $10^{\circ} \mathrm{C}$ isotherm for the warmest month and the warm index of $15^{\circ} \mathrm{C} \cdot$ months are used to study the implications of mass elevation effect for the MABs.

Firstly, according to the estimated air temperature data and ASTER GDEM, air temperatures and altitudes at the sites of MABs are extracted. Secondly, for the east edges or the neighboring areas, the extracted air temperatures were adjusted to the higher altitudes by Equation (1):

$$
T_{\text {adjusted }}=T+(h-H) \times \partial
$$

where $\partial$ is the lapse rate, $T$ is the air temperature at a height $h$ and $T_{\text {adjusted }}$ is the adjusted air temperature at an elevation $H$. There are several lapse rate data available in the western Sichuan Basin, between 0.42 and $0.60^{\circ} \mathrm{C} / 100 \mathrm{~m}^{-1}$ (Liu, 1992; Wu, 1996; Zheng et al., 1986; Xie 2006), and the lapse rates measured in Mt. Emei $\left(0.55^{\circ} \mathrm{C} / 100 \mathrm{~m}^{-1}\right.$ for July and $0.51^{\circ} \mathrm{C} /$ $100 \mathrm{~m}^{-1}$ for January) is relatively creditable, for Mt. Emei is located at the southwestern edge of the Sichuan Basin and at the easternmost edge of the Hengduan Mountains Therefore, the lapse rates of Mt. Emei were selected for the air temperature adjustment calculations in this paper (Table 1).

We then projected the elevation at which occurs the $10^{\circ} \mathrm{C}$ isotherm for the warmest month mean temperature and the warmth index (WI) at $4500 \mathrm{~m}$ (which corresponds to the mean elevation of the main plateau) based on the estimated monthly mean air temperatures and the ASTER GDEM data. The $10^{\circ} \mathrm{C}$ isotherms were extracted from the estimated air temperature data, and the corresponding altitudes were obtained from the ASTER GDEM data using ArcGIS. WI at the mean elevation of the main plateau (4500 $\mathrm{m}$ asl) is calculated as follows:

$$
W I=\sum(t-5)
$$

where $t$ is the monthly mean air temperature at $4500 \mathrm{~m}$ asl and $W I$ is the sum of $(t-5)$ for months in which $t$ exceeds $5^{\circ} \mathrm{C}$ (Kira, 1948; Ohsawa, 1990). Previous studies have shown that the warmest month $10^{\circ} \mathrm{C}$ isotherm and $15^{\circ} \mathrm{C} \cdot$ month warmth index exhibit the best overall occurrence of forest upper limits (Troll, 1973; Ohsawa, 1990). These climatic indexes could be used to explore the potential altitude of treelines and the correlation between mass elevation effect and the MABs/treeline position.

\section{Results}




\subsection{MABs and treelines rise gradually from the easternmost to the interior plateau}

(1) Montane dark coniferous forest

Along the Mt. Erlang-Nyainqentanglha profile, montane dark coniferous forest rises westwards: at about 2200-2900 m in the westernmost Sichuan Province (such as Mt. Emei and Mt. Erlang), at about 3000-4000 $\mathrm{m}$ at the eastern edges of the Plateau (such as Mt. Gongga, Mt. Zheduo and Mt. Gaoshi), up to $3000-4300 \mathrm{~m}$ in the Hengduan Mts. (such as Mt. Shaluli and Mt. Ningjing), and even up to $3200-4500 \mathrm{~m}$ in the interior TP (Figure 2a). The same trend is observed along the Mt. Guangguang-Tuoba Beishan profile: about 2400-3700 $\mathrm{m}$ of the eastern edges of the Plateau (such as Beichuan, Mt. Guangguang, and Mt. Siguliang), and about 3200-4400 m westward to the interior TP (such as Changdu) (Figure 2b).

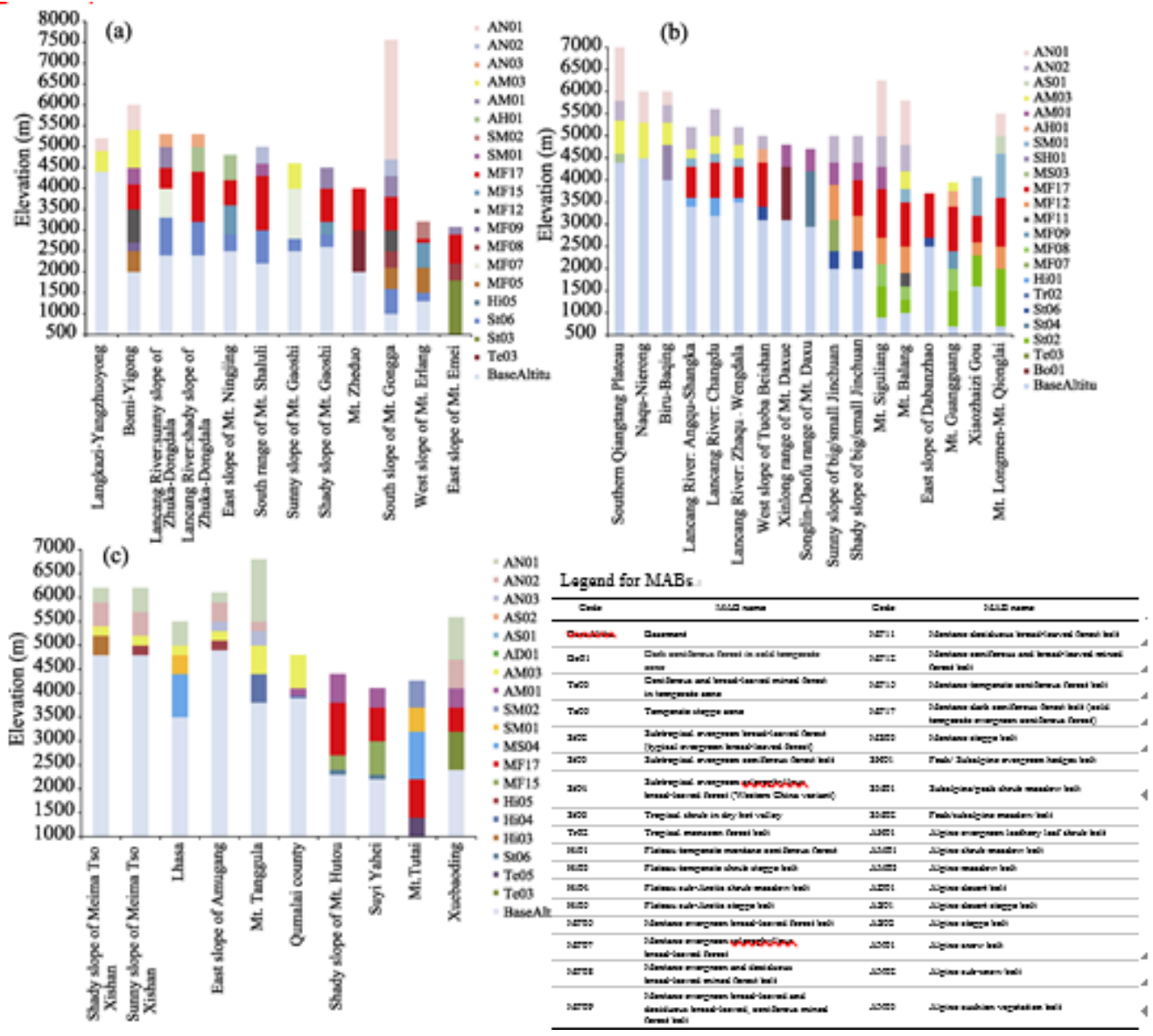

Figure 2 Mountain altitudinal belts along three profiles (a. the Mt. Erlang-Nyainqentanglha profile; b. the Mt. Guangguang-Tuoba Beishan profile; c. the Mt. Wutai-Amugang profile)

(2) Alpine shrub meadow and alpine meadow belts

Alpine meadow is at about $3700-4500 \mathrm{~m}$ in the eastern edges of the Plateau and rises to about $4400-5400 \mathrm{~m}$ in the interior TP. For example, along the Mt. Erlang-Nyainqentanglha profile, it is at $4000-4500 \mathrm{~m}$ at the eastern edges of the plateau (such as at Mt. Gaoshi) and about $4400-5400 \mathrm{~m}$ in the interior TP (such as at Bomi and Nyainqentanglha Mts.) (Figure 2a). Along the Mt. Guangguang-Tuoba Beishan profile, it is at about $3700-4200 \mathrm{~m}$ at the 
eastern edge of the plateau (such as at Mt. Guangguang and Mt. Siguliang) and 4500-5400 $\mathrm{m}$ in the interior TP (westward to Changdu) (Figure 2b). Along the Mt. Wutai-Amugang profile, it is at 3700-4400 $\mathrm{m}$ at the eastern edges of the Plateau, 4100-4800 $\mathrm{m}$ westward to the Qumalai county, 4400-5000 $\mathrm{m}$ in the Tangula Mts., and 5000-5400 $\mathrm{m}$ westward further to the interior $\mathrm{TP}$ (such as at Amugang) (Figure 2c).

(3) Treelines

Treelines also rise from the easternmost to the interior TP. Treelines are typically below $3700 \mathrm{~m}$ along the eastern edge of the TP. For example, $3200 \mathrm{~m}$ in the Qilian Mts., about 3250 $\mathrm{m}$ on Mt. Erlang, $3700 \mathrm{~m}$ on Minshan and Mt. Gongga. They ascend to about $4000 \mathrm{~m}$ east of the Maqin-Daofu-Jiulong line, and to 4600-4700 m westward in Zuogong and Lhasa, even up to $4900 \mathrm{~m}$ on some sunny slopes (Figure 1). Normally, treelines are about 1000-1500 m higher in the interior Plateau than in the eastern edges and adjacent lowlands.

In short, MABs and treelines all gradually ascend from the easternmost to the interior TP. This is the so-called "mass elevation effect (MEE)" (De Quervain, 1904; Grubb, 1971; Holtmeier, 2003), namely, growing season is longer and warmer at any given elevation in the interior mountains than in the outer mountain ranges. This makes treelines rise by about 400 $\mathrm{m}$ in the central Alps compared to the outer ranges (Barry, 2008; Holtmeier, 2003). As for the TP, MEE is much stronger due to its supersize body.

\subsection{Mass elevation effect of the TP}

(1) Gradual increase of air temperatures at the same elevation from the easternmost to the interior plateau

The air temperatures at the MABs sites on the eastern edges are adjusted to the altitudes of the sites on the interior TP by Equation (1) (shown in Table 2). Along the Mt. ErlangNyainqentanglha profile, monthly mean temperature is below $-12^{\circ} \mathrm{C}$ for January and $2{ }^{\circ} \mathrm{C}$ for July at $5292 \mathrm{~m}$ on the east of Mt. Gaoshi, and it is above $-11^{\circ} \mathrm{C}$ and $4{ }^{\circ} \mathrm{C}$, respectively, at the same elevation in the interior TP. The same trend can be seen along the Mt. GuangguangTuoba Beishan profile and along the Mt. Wutai-Amugang profile (Table 2). That is to say, air temperatures at same elevations increase gradually from the easternmost to the interior plateau.

(2) Mass elevation effect of the Tibetan Plateau

Differences in monthly air temperature between the interior TP and the eastern edges of the plateau at same altitude are calculated as the measurement of mass elevation effect. Leshan, Pingwu and Lintao are three stations located at the eastern edges of the plateau or neighboring lowland, and their temperatures are adjusted to the altitudes of the stations in the interior TP with Equation (1) based on the lapse rates of Mt. Emei (Table 1). The results are shown in Table 3. At the altitude of Lhasa station $(3648.9 \mathrm{~m})$, the minimum and maximum differences between Lhasa and Leshan are $7.3^{\circ} \mathrm{C}$ (July) and $11^{\circ} \mathrm{C}$ (June); at the altitude of Zuogong station $(3780 \mathrm{~m})$, the minimum and maximum differences between Zuogong and Leshan are $4.2^{\circ} \mathrm{C}$ (November) and $8.8^{\circ} \mathrm{C}$ (June). Similarly, at the altitude of Anduo station (4800 m), the minimum and maximum differences between Anduo and Pingwu are $2.0^{\circ} \mathrm{C}$ (November) and $6.8^{\circ} \mathrm{C}$ (June); at the altitude of Seda station $(3893.9 \mathrm{~m})$, the minimum and maximum differences between Seda and Pingwu are $0.5^{\circ} \mathrm{C}$ (November) and $4.0^{\circ} \mathrm{C}$ (June). At the altitude of Wudaoliang station $(4612.2 \mathrm{~m})$, the minimum and maximum differences between 
Wudaoliang and Lintao are $1.5^{\circ} \mathrm{C}\left(\right.$ March) and $4.2^{\circ} \mathrm{C}$ (January).

Table 1 Reported lapse rates of the Mt. Emei $\left({ }^{\circ} \mathrm{C} / 100 \mathrm{~m}\right)$

\begin{tabular}{ccccccccccccc}
\hline Month & Jan. & Feb. & Mar. & Apr. & May & Jun. & Jul. & Aug. & Sept. & Oct. & Nov. & Dec. \\
\hline Lapse rate & 0.51 & 0.53 & 0.56 & 0.57 & 0.60 & 0.60 & 0.55 & 0.56 & 0.54 & 0.53 & 0.55 & 0.49 \\
\hline
\end{tabular}

Table 2 Temperatures and the adjusted temperatures in January and in July near the locations of MABs along the three W-E profiles

\begin{tabular}{|c|c|c|c|c|c|c|c|c|c|}
\hline Profiles & MAB sites & $\begin{array}{l}\text { Longi- } \\
\text { tude }\end{array}$ & $\begin{array}{l}\text { Lati- } \\
\text { tude }\end{array}$ & $\begin{array}{l}\text { Altit- } \\
\text { ude } \\
(\mathrm{m})\end{array}$ & $\begin{array}{c}\text { Air tem- } \\
\text { perature } \\
\text { in Jan. } \\
\left({ }^{\circ} \mathrm{C}\right)\end{array}$ & $\begin{array}{c}\text { Air tem- } \\
\text { perature } \\
\text { in July } \\
\left({ }^{\circ} \mathrm{C}\right)\end{array}$ & $\begin{array}{l}\text { Adjusted } \\
\text { height } \\
\text { (m) }\end{array}$ & $\begin{array}{c}\text { Adjusted } \\
\text { air tem- } \\
\text { perature } \\
\text { in Jan. } \\
\left({ }^{\circ} \mathrm{C}\right)\end{array}$ & $\begin{array}{l}\text { Adjusted } \\
\text { air tem- } \\
\text { perature } \\
\text { in Jul. } \\
\left({ }^{\circ} \mathrm{C}\right) \\
\end{array}$ \\
\hline \multirow{11}{*}{$\begin{array}{l}\text { Mt.Erlang- } \\
\text { Nyainqentanglha }\end{array}$} & Langkazi-Yangzhuoyong & 90.50 & 29.70 & 5292 & -10.23 & 6.58 & \multirow{11}{*}{5292} & -10.2 & 6.6 \\
\hline & Bomi-Yigong & 94.62 & 30.17 & 5096 & -10.08 & 8.12 & & -11.1 & 7.0 \\
\hline & Zhuka-Dongdala shady slope & 98.64 & 29.70 & 4496 & -5.64 & 10.12 & & -9.7 & 5.7 \\
\hline & Zhuka-Dongdala sunny slope & 98.56 & 29.75 & 4050 & -4.23 & 11.36 & & -10.6 & 4.5 \\
\hline & East slope of Mt. Ningjing & 99.00 & 29.83 & 3455 & 0.46 & 14.98 & & -8.9 & 4.9 \\
\hline & South range of Shaluli & 99.73 & 29.75 & 4483 & -4.75 & 10.35 & & -8.9 & 5.9 \\
\hline & Mt. Gaoshi & 101.00 & 30.03 & 3226 & -1.91 & 13.37 & & -12.5 & 2.0 \\
\hline & Mt. Zheduo & 101.80 & 30.10 & 4218 & -7.37 & 9.46 & & -12.5 & 3.6 \\
\hline & South slope of Mt.Gongga & 102.07 & 29.39 & 2077 & -2.45 & 15.90 & & -12.8 & -1.8 \\
\hline & West slope of Mt. Erlang & 102.56 & 30.12 & 3199 & -5.07 & 13.12 & & -18.8 & 1.6 \\
\hline & East slope of Mt. Emei & 103.45 & 29.58 & 473 & 4.96 & 26.65 & & -21.5 & 0.1 \\
\hline \multirow{15}{*}{$\begin{array}{l}\text { Mt.Guang- } \\
\text { guang- } \\
\text { Tuoba } \\
\text { Beishan }\end{array}$} & Southern Qiangtang Plateau & 90.00 & 31.33 & 4943 & -12.24 & 8.44 & \multirow{15}{*}{4943} & -12.24 & 8.44 \\
\hline & Naqu-Nierong & 92.17 & 31.63 & 4636 & -10.18 & 9.96 & & -11.75 & 8.28 \\
\hline & Shady slope of Biru-Baqing & 94.59 & 31.50 & 4417 & -8.79 & 9.85 & & -11.48 & 6.95 \\
\hline & Lancang River: Angqu-Shangka & 96.84 & 31.45 & 3605 & -3.47 & 13.73 & & -10.29 & 6.37 \\
\hline & Lancang River: Changdu & 97.17 & 31.45 & 3533 & -5.84 & 12.78 & & -13.03 & 5.03 \\
\hline & $\begin{array}{l}\text { Lancang River: Zhaqu-Weng } \\
\text { Dagang }\end{array}$ & 97.21 & 31.52 & 3675 & -2.31 & 13.89 & & -8.78 & 6.92 \\
\hline & East slope of Beishanin Tuoba & 97.97 & 31.53 & 4321 & -9.02 & 9.22 & & -12.19 & 5.80 \\
\hline & Xinlong of Mt. Daxueshan & 100.31 & 30.94 & 3189 & -4.21 & 12.62 & & -13.15 & 2.98 \\
\hline & Songlinkou-Daofu of Mt. Daxue & 101.12 & 30.98 & 2934 & -2.18 & 15.82 & & -12.42 & 4.77 \\
\hline & Big/small Jinchuan & 102.06 & 31.48 & 2540 & -0.02 & 17.60 & & -12.28 & 4.38 \\
\hline & Mt. Siguliang & 102.90 & 31.10 & 3950 & -10.54 & 11.90 & & -15.60 & 6.44 \\
\hline & Mt. Balang & 103.17 & 31.07 & 4047 & -7.63 & 7.89 & & -12.20 & 2.96 \\
\hline & South slope of Dabanzhao & 103.05 & 31.67 & 3794 & -11.93 & 11.16 & & -17.79 & 4.84 \\
\hline & Mt. Guangguang & 103.61 & 31.01 & 745 & 5.61 & 25.53 & & -15.80 & 2.44 \\
\hline & Small Zhaizigou & 103.80 & 31.35 & 3392 & -5.10 & 13.64 & & -13.01 & 5.11 \\
\hline \multirow{7}{*}{$\begin{array}{l}\text { Mt.Wutai- } \\
\text { Amugang }\end{array}$} & $\begin{array}{l}\text { Shady slope of Memar } \\
\text { Tso Xishan }\end{array}$ & 81.83 & 34.45 & 5090 & -14.31 & 8.30 & \multirow{7}{*}{5742} & -17.64 & 4.71 \\
\hline & $\begin{array}{l}\text { Sunny slope of Memar } \\
\text { Tso Xishan }\end{array}$ & 82.38 & 34.28 & 5282 & -14.24 & 7.62 & & -16.59 & 5.09 \\
\hline & East slope of Amugang & 85.50 & 33.50 & 5742 & -17.99 & 5.15 & & -17.99 & 5.15 \\
\hline & Tanggula Mts. & 89.92 & 33.20 & 5018 & -13.86 & 8.50 & & -17.55 & 4.52 \\
\hline & Qumalai County & 95.78 & 34.13 & 4149 & -11.30 & 11.10 & & -19.42 & 2.34 \\
\hline & Shady slope of Hutou Shan & 103.22 & 34.07 & 2471 & -9.23 & 17.00 & & -25.92 & -0.99 \\
\hline & Xuebaoding & 103.62 & 32.88 & 3723 & -9.32 & 10.22 & & -19.62 & -0.88 \\
\hline
\end{tabular}


Table 3 Temperature and temperature differences of typical observation stations between the main plateau and surrounding areas $\left({ }^{\circ} \mathrm{C}\right)$

\begin{tabular}{lcrrrrrrrrrrrrrrr}
\hline \multicolumn{1}{c}{ Stations } & Lat. & Long. Elev.(m) & Jan. & Feb. & Mar. & Apr. & May & Jun. & Jul. & Aug. & Sept. & Oct. & Nov. & Dec. \\
\hline Lhasa & 29.7 & 91.1 & 3648.9 & 0.6 & 3.0 & 6.3 & 8.7 & 12.7 & 16.1 & 16.5 & 16.1 & 14.2 & 9.7 & 4.0 & 0.8 \\
Zuogong & 29.7 & 97.8 & 3780 & -3.9 & -1.9 & 1.5 & 5.0 & 8.7 & 13.0 & 13.3 & 12.8 & 10.9 & 6.2 & 0.0 & -3.4 \\
Leshan & 29.6 & 103.8 & 424.2 & 7.4 & 10.7 & 14.3 & 19.0 & 22.4 & 24.4 & 26.9 & 26.0 & 22.8 & 18.3 & 14.2 & 8.7 \\
$\mathrm{~T}_{\text {Lhasa-Leshan }}$ & & & 3648.9 & 9.7 & 9.4 & 10.1 & 8.2 & 9.6 & 11.0 & 7.3 & 8.2 & 8.9 & 8.4 & 7.5 & 7.8 \\
$\mathrm{~T}_{\text {Zuogong-Leshan }}$ & & & 3780 & 5.9 & 5.2 & 6.0 & 5.1 & 6.4 & 8.8 & 4.8 & 5.6 & 6.2 & 5.6 & 4.2 & 4.3 \\
Anduo & 32.4 & 91.1 & 4800 & -12.3 & -10.4 & -6.4 & -2.1 & 2.0 & 6.0 & 8.4 & 8.2 & 5.3 & -1.2 & -8.5 & -11.3 \\
Seda & 32.3 & 100.3 & 3893.9 & -9.6 & -6.7 & -3.0 & 1.6 & 4.9 & 8.7 & 10.7 & 10.1 & 7.3 & 1.7 & -5.2 & -8.4 \\
Pingwu & 32.4 & 104.5 & 893.2 & 4.7 & 7.9 & 11.7 & 16.2 & 19.8 & 22.7 & 24.8 & 23.3 & 19.6 & 15.4 & 10.9 & 5.5 \\
$\mathrm{~T}_{\text {Anduo-Pingwu }}$ & & & 4800 & 2.9 & 2.4 & 3.8 & 4.0 & 5.6 & 6.8 & 5.1 & 6.7 & 6.8 & 4.1 & 2.0 & 2.4 \\
$\mathrm{~T}_{\text {Seda-Pingwu }}$ & & & 3893.9 & 0.9 & 1.3 & 2.1 & 2.5 & 3.1 & 4.0 & 2.4 & 3.6 & 3.9 & 2.2 & 0.5 & 0.8 \\
Wudaoliang & 35.2 & 93.1 & 4612.2 & -15.3 & -13.0 & -9.6 & -4.5 & -0.8 & 3.1 & 6.7 & 6.2 & 2.7 & -4.3 & -11.0 & -14.1 \\
Lintao & 35.4 & 103.9 & 1893.8 & -5.7 & -0.7 & 4.2 & 9.5 & 13.7 & 17.1 & 19.3 & 18.7 & 13.8 & 8.3 & 1.7 & -4.5 \\
$\mathrm{~T}_{\text {Wudaoliang-Lintao }}$ & & & 4612.2 & 4.2 & 2.1 & 1.5 & 1.5 & 1.8 & 2.3 & 2.3 & 2.7 & 3.5 & 1.8 & 2.2 & 3.7 \\
\hline
\end{tabular}

Yao and Zhang (2014) calculated the air temperature differences at the altitude of $4500 \mathrm{~m}$ between the main plateau and the adjacent lowlands or at the eastern edges. The temperature difference between the southern plateau and the Sichuan Basin is $5.25^{\circ} \mathrm{C}$ for the coldest month (January) and $4.86^{\circ} \mathrm{C}$ for the warmest month (July); the minimum and maximum differences are $3.58^{\circ} \mathrm{C}$ (April) and $6.63^{\circ} \mathrm{C}$ (June), respectively (Table 4). In short, monthly mean air temperature in the main plateau is approximately $2-7^{\circ} \mathrm{C}$ higher than in the surrounding mountains and adjacent lowland areas. This analysis verifies that the main plateau is warmer than its surroundings and adjacent lowland areas at the plateau surface elevation and gives rise to so-called "mass elevation effect" of the plateau.

Table 4 Monthly temperatures and temperature differences $(\Delta \mathrm{T})$ between the main plateau and the surrounding/adjacent lowland areas at an altitude of $4500 \mathrm{~m}\left({ }^{\circ} \mathrm{C}\right)$

\begin{tabular}{lccccccccccccc}
\hline & Jan. & Feb. & Mar. & Apr. & May & Jun. & Jul. & Aug. & Sept. & Oct. & Nov. & Dec. \\
\hline Main Plateau & -10.19 & -8.16 & -4.73 & -0.1 & 3.77 & 7.83 & 9.94 & 9.59 & 6.9 & 0.13 & -6.3 & -9.14 \\
Hengduan Mts. & -7.07 & -5.28 & -2.27 & 0.83 & 5.21 & 8.2 & 10.08 & 9.93 & 7.2 & 2.12 & -3.84 & -6.52 \\
Southern main TP & -7.55 & -6.08 & -2.85 & 0.83 & 4.42 & 8.5 & 10.22 & 9.89 & 7.5 & 2 & -3.6 & -6.4 \\
Central main TP & -10.8 & -8.26 & -4.41 & 0.21 & 4.02 & 8.45 & 10.56 & 10.11 & 7.39 & 0.49 & -6.22 & -9.56 \\
Northern main TP & -13.48 & -11.17 & -7.58 & -1.37 & 3.01 & 6.95 & 9.44 & 9.00 & 6.16 & -2.41 & -9.55 & -12.31 \\
Qilian Mts. & -17.41 & -15.58 & -12.08 & -4.19 & 2.11 & 6.13 & 8.94 & 7.93 & 4.4 & -5.44 & -13.08 & -17.16 \\
Sichuan Basin & -12.8 & -10.29 & -7.16 & -2.75 & -0.41 & 1.87 & 5.36 & 4.15 & 1.54 & -2.23 & -7.63 & -10.94 \\
$\Delta \mathrm{T}_{\text {Hengduan-Sichuan }}$ & 5.73 & 5.01 & 4.89 & 3.58 & 5.62 & 6.33 & 4.72 & 5.78 & 5.66 & 4.35 & 3.79 & 4.42 \\
$\Delta \mathrm{T}_{\text {Southern TP-Sichuan }}$ & 5.25 & 4.21 & 4.31 & 3.58 & 4.83 & 6.63 & 4.86 & 5.74 & 5.96 & 4.23 & 4.03 & 4.54 \\
$\Delta \mathrm{T}_{\text {Central TP-Qilian }}$ & 6.61 & 7.32 & 7.67 & 4.4 & 1.91 & 2.32 & 1.62 & 2.18 & 2.99 & 5.93 & 6.86 & 7.60 \\
$\Delta \mathrm{T}_{\text {Northern TP-Qilian }}$ & 3.93 & 4.41 & 4.5 & 2.82 & 0.9 & 0.82 & 0.5 & 1.07 & 1.76 & 3.03 & 3.53 & 4.85 \\
\hline
\end{tabular}

Note: cited from Yao and Zhang (2014). 


\subsection{Implication of mass elevation effect for the MABs/treelines}

On both global and continental scales, temperature is, to a great extent, the final factor for determining treeline altitude and the MABs (Holtmeier and Broll, 2005). It has been also proved that the warmest month $10^{\circ} \mathrm{C}$ isotherm and the warmth index of $15^{\circ} \mathrm{C} \cdot$ month coincide quite well with alpine treelines, especially in temperate areas (Troll, 1973; Ohsawa, 1990). The warmest month $10^{\circ} \mathrm{C}$ isotherm is below $4000 \mathrm{~m}$ in the Qilian Mts. and the eastern edges of the plateau, and ascends to $4000-4600 \mathrm{~m}$ in the Hengduan Mts. It goes up to $4600-4700 \mathrm{~m}$ westward in Zuogong and Lhasa and even up to 5000-6000 $\mathrm{m}$ westward in the areas of Ga'erGêrzê (Figure 3). Warmth index of $15^{\circ} \mathrm{C} \cdot$ month occurs above the altitude of $4500 \mathrm{~m}$ in the Hengduan Mts. and the southern and central parts of the plateau.

The analysis above shows that air temperature is warmer in the interior than at the eastern edges of the plateau at given elevation due to its mass elevation effect. That explains why treelines are 1000-1500 $\mathrm{m}$ higher in the interior than in its outer slopes and surrounding areas of the TP.

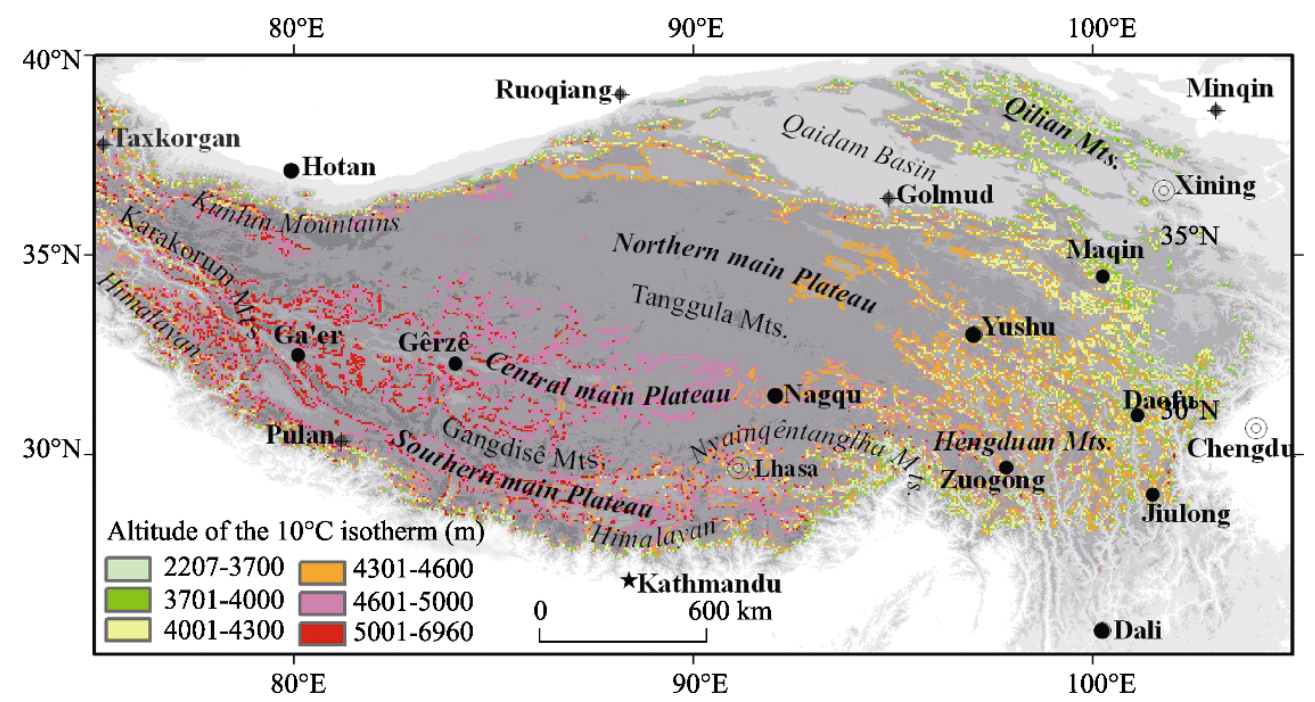

Figure 3 Spatial distribution of the $10^{\circ} \mathrm{C}$ isotherm for the warmest month on the Tibetan Plateau

\section{Discussion and conclusions}

\subsection{Discussion}

(1) Precipitation is also significant for the distribution of treelines and MABs

Although the warmest month $10^{\circ} \mathrm{C}$ isotherm is at the highest elevation of $5000-6000 \mathrm{~m}$ in Ga'er-Gêrzê of the southwestern TP and the highest warmth index occurs in the central TP, the highest treeline in the Northern Hemisphere does not occur in the central or the southwestern TP but in the southeastern plateau. This is because tree growth requires a certain amount of annual precipitation, at least $500 \mathrm{~mm}$ in plain areas and $300 \mathrm{~mm}$ in some high mountains (Hou, 1982). In the southwest, north and heartland of the TP, the annual precipitation is only about 50-300 mm (Liao, 1990; Zheng and Li, 1990; Zhang et al., 2002; Wang et al., 2011). It amounts to $500-1000 \mathrm{~mm}$ in the southeastern part of the plateau. As a 
result, the highest treeline in the Northern Hemisphere occurs in the southeastern TP.

(2) Temperature lapse rate on the TP needs in-depth study

When studying mountain climates, temperature lapse rate is typically a necessary parameter (Rolland, 2003). However, there are few reports regarding the seasonal variation in lapse rates on TP. In this study, lapse rates measured on Mt. Emei were used for temperature adjustment calculations in the Sichuan Basin according to the reported references (Table 1). Strictly speaking, the lapse rate of Mt. Emei cannot be representative for the whole TP. Lapse rates on the TP may be smaller than that of Mt. Emei due to its MEE, and temperature lapse rates are usually steeper on isolated mountains near the sea than within extensive mountain ranges that provide their own heating (Hastenrath, 1968; Flenley, 1995). It has also been noted that lapse rates exhibit considerable variability in relation to the climatic zone, season (Hastenrath, 1968), air mass types (Yoshino, 1966) and local topography (Flenley, 2007; Barry, 2008). Thus monthly mean lapse rates on the TP and their spatiotemporal variation deserve a closer examination in the future.

(3) Comparative studies of mass elevation effect and its implications for MABs are necessary

Any massive mountains or plateaus must have great MEE. But the magnitude of MEE varies from mountain to mountain, and its implication differs for MABs and treelines in different regions. The highest snowline and treeline occur on the TP for the Northern Hemisphere, and in the central Andes for the Southern Hemisphere. The TP and the central Andes must have the greatest MEE. So, comparative studies of mass elevation effect and its implications for MABs will help disclose the mechanism of interactions between mountain complex ecological patterns and mass elevation effect.

\subsection{Conclusions}

(1) Due to MEE, air temperature is higher in the interior TP than in eastern edges at given elevations. At the average height $(4500 \mathrm{~m})$ of the TP, air temperatures are 3.58 (in April)$6.63^{\circ} \mathrm{C}$ (in June) higher in the interior TP than in the Sichuan Basin. The $10^{\circ} \mathrm{C}$ isotherm of the warmest month goes upward from the eastern border to the interior of the plateau, e.g., 4000 $\mathrm{m}$ in the Qilian Mts. and up to $4600-5000 \mathrm{~m}$ in Lhasa and Zuogong. Warmth index at an altitude of $4500 \mathrm{~m}$ in the interior $\mathrm{TP}$ can be up to over $15^{\circ} \mathrm{C} \cdot \mathrm{month}$, but lower than $15^{\circ} \mathrm{C} \cdot$ month at the same elevation at the eastern edges of the TP.

(2) Air temperature, MABs and treelines follow a similar trend of rising inwards due to MEE. Dark coniferous forest is 1000-1500 m higher, alpine steppe belts 700-900 m higher, and treelines 1000-1500 $\mathrm{m}$ higher in the interior plateau than at the eastern edges.

\section{References}

Barry R G, 2008. Mountain Weather and Climate. Boulder, USA: Cambridge University Press.

Chen Longxun, Reiter E R, Feng Zhiqiang, 1985. The atmospheric heat-source over the Tibetan Plateau: MayAugust 1979. Monthly Weather Review, 113: 1771-1790.

De Quervain A, 1904. Die Hebung der atmosphärischen Isothermen in den Schweizer Alpen und ihre Beziehung zu den Höhengrenzen. Gerlands Beiträge zur Geophysik, 6: 481-533

Flenley J R, 1995. Cloud forest, the Massenerhebung effect, and ultraviolet insolation. Ecological Studies, 110: 
150-155.

Flohn H, 1951. Some remarks on the annual trend of weather in the Scottish highlands. Quarterly Journal of the Royal Meteorological Society, 77(334): 674-675.

Flohn H, 1957. Large-scale aspects of the "summer monsoon" in South and East Asia. Journal of the Meteorological Society of Japan, 75: 180-186.

Grubb P J, 1971. Interpretation of Massenerhebung effect on tropical mountains. Nature, 229(5279): 44-45.

Han Fang, Yao Yonghui, Dai Shibao et al., 2012. Mass elevation effect and its forcing on timberline altitude. Journal of Geographical Sciences, 22(4): 609-616.

Hastenrath S, 1968. Certain aspects of the three-dimensional distribution of climate and vegetation belts in the mountains of Central America and southern Mexico. Colloquium Geography, 9: 122-130.

Hoch G, Körner C, 2005. Growth, demography and carbon relations of Polylepis trees at the world's highest treeline. Function of Ecology, 19(6): 941-951.

Holtmeier F K, 2003. Mountain Timberlines: Ecology, Patchiness, and Dynamics. Dordrecht, Boston: Kluwer Academic Publishers.

Hou Xueyu, 1982. China Vegetation Geography and Dominant Plant Composition. Beijing: Science Press. (in Chinese)

Li Qiaoyuan, Xie Zichu, 2006. Analyses on the characteristics of the vertical lapse rates of temperature: Take Tibetan Plateau and its adjacent area as an example. Journal of Shihezi University (Natural Science), 24(6): 719723. (in Chinese)

Liao Ke, 1990. The Atlas of the Tibetan Plateau. Beijing: Science Press. (in Chinese)

Liu Dongshen, Sun Honglie, Zheng Du, 2003. The Tibet Plateau research's scientific paradigm, effect and its spiritual connotation. http: www2.cas.cn/html/Dir/2003/10/14/2458.htm. (in Chinese)

Liu Kaifa, 1992. Climate of the Emei Shan. Journal of Mianyang Agricultural College, 9(3): 44-48. (in Chinese)

Miehe G, Miehe S, Vogel J et al., 2007. Highest treeline in the Northern Hemisphere found in southern Tibet. Mountain Research and Development, 27(2): 169-173.

Ohsawa M, 1990. An interpretation of latitudinal patterns of forest limits in South and East Asian mountains. Journal of Ecology, 78(2): 326-339.

Shi Yafeng, Zheng Benxing, Li Shijie, 1992. Last Glaciation and Maximum Glaciation in the Qinghai-Xizang (Tibet) Plateau: A controversy to M. Kuhle's ice sheet hypothesis. Chinese Geographical Science, 2(4): $293-311$.

Sun Ranhao, Zhang Baiping, 2008. Exploring the method of digital identification of mountain altitudinal belts. Geoinformation Science, 10(6): 690-696. (in Chinese)

Sun Ranhao, Zhang Baiping, Tan Jing, 2008. A multivariate regression model for predicting precipitation in the Daqing Mountains. Mountain Research and Development, 28(3): 318-325.

Tollner H, 1949. Der Einfluß großer Massenerhebungen auf die Luftemperatur und die Ursachen der Hebung der Vegetationsgrenzen in den inneren Ostalpen. Theoretical and Applied Climatology, 1(3): 347-372.

Troll C, 1973. The upper timberlines in different climatic zones. Arctic and Alpine Research, 5(3): 3-18.

Wang Chuanhui, Zhou Shunwu, Tang Xiaoping et al., 2011. Temporal and spatial distribution of heavy precipitation over Tibetan Plateau in recent 48 years. Scientia Geographica Sinica, 31(4): 470-477. (in Chinese)

Wu Guoxiong, Liu Yiming, Liu Xin et al., 2005. How the heating over the Tibetan Plateau affects the Asian climate in summer. Chinese Journal of Atmospheric Sciences, 29(1): 47-57. (in Chinese)

Wu Zhangwen, 1996. Local climate measurement of Qingcheng Shan. Journal of Sichuan Forestry Science and Technology, 17(1): 74-76. (in Chinese)

Yao Yonghui, Zhang Baiping, 2013a. A preliminary study of the heating effect of the Tibetan Plateau. PLOS One. doi: 10.1371/journal.pone.0068750.

Yao Yonghui, Zhang Baiping, 2013b. MODIS-based estimation of air temperature of the Tibetan Plateau. Journal of Geographical Sciences, 23(4): 627-640.

Yao Yonghui, Zhang Baiping, 2013c. MODIS-based estimation of air temperature and heating effect of the Tibetan Plateau. Acta Geographica Sinica, 68(1): 93-104. (in Chinese)

Yao Yonghui, Zhang Baiping, 2014. The mass elevation effect of the Tibetan Plateau and its implications for Alpine 
treelines. International Journal of Climatology. doi: 10.1002/joc.4123.

Ye Duzheng, 1982. Some aspects of the thermal influences of Qinghai-Tibetan Plateau on the atmospheric circulation. Archives for Meteorology, Geophysics, and Bioclimatology, 31(3): 205-225.

Ye Duzheng, Luo Siwei, Zhu Baozhen, 1957. The flow pattern and heat budget in the troposphere over the Tibetan Plateau and surrounding area. Acta Meteorologica Sinica, 28(2): 108-121. (in Chinese)

Zhang Baiping, 2008. Progress in the study on digital mountain altitudinal belts. Journal of Mountain Science, 26(1): 12-14. (in Chinese)

Zhang Baiping, Chen Xiaodong, Li Baolin et al., 2002. Biodiversity and conservation in the Tibetan Plateau. Journal of Geographical Sciences, 12(2): 135-143.

Zhang Baiping, Tan Jing, Yao Yonghui, 2009. Digital Information and Patterns of Mountain Altitudinal Belts. Beijing: China Environmental Sciences Press. (in Chinese)

Zhao Fang, Zhang Baiping, Tan Jing et al., 2011. Structure and function of the digital integrated system for the Eurasian mountain altitudinal belt. Journal of Geo-information Science, 13(3): 346-355. (in Chinese)

Zhao Y, Li H J, Huang A N et al., 2013. Relationship between thermal anomalies in Tibetan Plateau and summer dust storm frequency over Tarim Basin, China. Journal of Arid Land, 5(1): 25-31.

Zheng Du, Li Bingyuan, 1990. Evolution and differentiation of the natural environment of the Qinghai-Tibet Plateau. Geographical Research, 9(2): 1-10. (in Chinese)

Zheng Yuanchang, Gao Shenghuai, Chai Zongxin, 1986. A preliminary study on the vertical natural zones in the Hengduan Mountainous region. Mountain Research, 4(1): 75-83. (in Chinese) 